\title{
The Research of Construction for Teaching Management Informatization of University under the Credit System
}

\author{
Baohua Cui \\ Economic Management Department, \\ Jilin Agricultural University, \\ Changchun, China \\ Email: cbhjlau@yeah.net
}

Key words: credit system ; teaching management ; informatization

\begin{abstract}
Great changes have occurred in work flow of educational administration in universities, which increases the difficulty and work load of educational ministration.
\end{abstract}

This paper elaborated that the informatization of teaching management information was the inevitable requirement of credit management, noted the difficulties in implementation process of teaching management informatization under the credit system, and gave the reasonable proposals.

\section{Introduction}

Currently, educational management of university implement reforms of credit, see credit and grade points as a measure of the quantity and quality of students' learning, so that students choose learning contents by themselves, allow students to adjust the learning process flexibility, which is a kind of teaching management for students' learning process on the whole counseling by teachers. In the popular context of higher education, educational administration guarantee normal operation of the school-running system throughout colleges and universities, determines the quality of education and management level of schools, how to build the informatization of teaching management of universities under credit system, which is still a currently problem faced by many colleges and universities .

\section{Informatization of teaching management is the necessary condition of credit management}

"Key Points of Education Management in Higher School" issued by the Ministry of Education stated that the basic task is to study teaching and management rules, improve teaching management, improve teaching management level; establish stable teaching order, ensure the normal operation of teaching ; study and implement education reforms. Try our best to mobilize initiative of teaching and learning from teachers and students. Teaching management of university is an important part of college management, is a kind of highly scientific work, follow not only the laws of education and teaching, but also the rules of management work. Teaching Management informatization of university mainly uses information technology to change the organization of teaching management information in order to accelerate handling, transfer and feedback process of the management information,and ultimately reaches the goal to improve the efficiency of teaching management.In the process of credit management, school leaders, educational administrators, teachers and students require handling and retrieval of information conveniently and efficiently, efficiently collect, process and deal with information of educational management using information technology, transfer information of educational administration to all teachers and students timely and accurately, complete teaching management process of credit system $^{[1]}$. At the same time,educational management informatization can meet the different needs according to different users,making 
management more personalized and humanized. The use of informational management tools, make it easier to consult timely teaching information for teachers and students. Educational management is a kind of complicated work which always has a very large amount of information from students' enrollment, every information of task are complicated and can't be wrong.. In the popular context of higher education, a growing number of students forces a much larger amount of information of educational management, a more difficult of information collection,the teaching managements of traditional artificial way delay not only information feedback, lower efficiency and accuracy of information, but easily make mistakes, which apparently can't adapt to the new needs of management model of university, educational administration informatization of university under the credit has become essential.

\section{The implementarydifficulty of teaching management informatization under credit system in the university}

\section{A. The little understanding for informatization construction of educational management from implementary subject}

The understanding for content and importance of teaching management informatization islittle,theconcepts of teaching management are old-fashioned. On one hand, the decision-makersof school are not fully aware of the importance of informatization, although some universitieshave done some work in this regard, they don't establish leadership decision-making department of educational informatization, nor to form the corresponding information technology team, which restrict the development of informatization in the universities in a large part. On the other hand, teachers and administrators refuse to accept new things, take little interest in taking part in training of informatization construction, refuse to accept software system of teaching management, which lead to passive and lagging informatization construction of teaching management ${ }^{[2]}$.

\section{B. The aim for teaching management informatization is not clear, and the project is lack on the whole}

The process of informatization is accelerating, which has brought new challenges for college teaching management. Currently, many institutions of higher education administrators have been aware of this point, set up a network center, carry out project of teaching management informatization. But because they do not have a deep understanding for aims and tasks of teaching management informatization, at the same time they are lack of overall system planning, which result in slow progress of teaching management informatization, although existing information systems of teaching management meet the demand of some part business, still can't meet needs for information of teaching management.

\section{Flexibility, extendibility and openness are poor, upgrade and maintaining are difficult}

Deepening teaching reform, and constant adjustive professional training programs and adjustive campuses location of schools and faculties, which make the requirements increasing for flexibility of educational management information system. Educational management system often occur problems in practical operation, for example, rationality problem in building block, lagging problem that planning and design of the system can't keep with the needs of reforms and development in university teaching ${ }^{[3]}$. The educational administration system of university can't be used stably in a long time because of existing problem , as a result, the universities need timely to update and upgrade system, which will not only waste manpower and material resources, but restrict the reform and development of school.

\section{Low quality of teaching administrators}

Teaching administrators as administrative practitioners in universities teaching play an important role in informative construction of teaching administration. Low quality of teaching administrators become a bottleneck in informative construction of teaching administration, which are also difficult to play its corresponding role in it. Operational capability without informative 
construction of teaching administration can't achieve the computer operating level that teaching administrators should possess, when they deal with interactive information in face of teaching administrative system. Viewing the situation as the whole, currently teaching administrators are lack of informative processing capabilities in general, which perplex the implementation of informative construction of teaching administration.

\section{Practical measure of informative administration in the university teaching under the credit}

\section{A. Innovate the concepts of teaching administration}

First, innovation for the concept of educational administration requires teaching administrators who should have a global view, set out the whole planning schedule in line with school's development, have a unified planning and construction for hardware and software platform, have a centralized management, and can optimize resources. Secondly, it requires them to completely change traditional administrative methods and means, tries to learn and master necessary informative technology of teaching administration in order to improve management efficiency. Third, we must strengthen the concepts of teaching management, run the training model reforms with the solid foundation, wide requirements, complex innovative talents through curriculum, teaching methods and administrative methods. We should strengthen constructive concept of disciplines, adjust and merge timely the original disciplines and professional settings, open new disciplines and new profession in line with development of science and technology. We strengthen the service concept, straighten operating mechanism of teaching administration, establish the concept of management as a service, realize administrative technological innovation and service innovation, improve the efficiency of educational administration ${ }^{[4]}$.

\section{B. Make institution and mechanism of teaching administration perfect}

According to the local conditions, setting up all kinds of rules and regulations which have a strong operation and suit for the goals of informative construction, is a prerequisite for teaching administration informatization corresponding with credit in university. Establish and perfect the enrollment mechanism and register management system, optimize administrative mechanism of school routine, achieve scientific and standardized of the teaching management.Only system are standard, strict and operate easily, do we reflect the requirements of informative management. In the specific practice, educational administrators can timely find out problems in management processes and regulations and propose amendments, improve educational administration and mechanism on the basis of process control, make the teaching management standardized increasingly, realize teaching administrative level increasing continuously.

\section{Make informative system of educational administration perfect}

Informative system of education management is an important part of informative construction of teaching management. To make informative system of educational administration perfect is effective methods to improve informative construction of educational management. According to actual situation of teaching management, We should carry out specific informative construction of teaching management. In the view of current that every department is independent, we strengthen compatibility between systems, carry out informative construction of teaching management specific, try to make it integration in order to achieve the purpose of synergy cooperation between teaching management departments. Regarding to the non-integrated system, we combine with the relevant standards through the data analysis of system, carry out second development, establish a unified interface with teaching administrative system,make a complete and unified data, achieve the purpose of improving teaching administrative management ${ }^{[5]}$.

\section{Make guarantee mechanism of informative talents perfect}

Informatization is not only full application of computer function, the combinations between hardware and software, but demands the user's ability to control hardware and software. Therefore, informative talents are guarantee for educational administrative information under credit, we must 
develop a professional team with clear responsibilities, strong technical force and professional personnel. First of all, we should establish a sense of service of teaching administrative personnel, serving to the teaching, teachers and students. Secondly, we should pay attention to training professional skills of teaching administrators, make them master educational theory and professional knowledge, master modern information technology, have a good information quality.

\section{Conclusion}

Informatization construction of education and teaching management is a process of gradual improvement, it can not be achieved overnight. That requires lateral and longitudinal cooperation of personnel in the university administration, only when we face information society, make full use of existing resources and advantages, realize informational and scientific management, meanwhile make sure every link work accuracy, can we achieve further improvement for management informatization of education and teaching.

\section{References}

[1] Jia Lihua. Discussions on Teaching Management Mode of University Credit System, [J]. Research and Practice on Higher Education, 2011（6）.

[2] Li Yangxi. Research on Higher Education Management Mode under the Credit System, [J]. Heilongjiang Education(Higher Education Research \& Appraisal), 2009 (10) .

[3] Shen Cuiying. Exploration on New Model of College Student Management under Credit Teaching Management System, [J]. Journal of Changzhou Vocational and Technical College, 2012 (4).

[4] Mo Qinde, Li Ruigui, Wei Qiaoyan. On the necessity and implementation approach of university education management information, [J]. China Electric Power Education, 2010, 21

[5] Yang Minghui. Wan Aiguo, Sun Ning. Discussion on University information solutions, [J]. Guangdong Communication Technology, 2009, (7). 